Article

\title{
Food Safety Knowledge and Practices among Saudi Mothers
}

\author{
Wafa O. Ayaz ${ }^{1}$, Anushree Priyadarshini ${ }^{2, *(\mathbb{D})}$ and Amit K. Jaiswal ${ }^{1}$ \\ 1 School of Food Science and Environmental Health, College of Sciences and Health, Dublin Institute of \\ Technology, Cathal Brugha Street, Dublin D01 HV58, Ireland; d15125240@mydit.ie (W.O.A.); \\ amit.jaiswal@dit.ie or akjaiswal@outlook.com (A.K.J.) \\ 2 School of Accounting and Finance, College of Business, Dublin Institute of Technology, Aungier Street, \\ Dublin D02 HW71, Ireland \\ * Correspondence: anushree.priyadarshini@dit.ie; Tel.: +353-1-402-7147
}

Received: 8 October 2018; Accepted: 21 November 2018; Published: 25 November 2018

check for updates

\begin{abstract}
This study examines food safety knowledge and practices of mothers in Saudi Arabia. A total of 979 respondents participated in the study and completed a questionnaire that assessed their knowledge of food storage, food handling, usage, and maintenance of kitchen facilities, personal hygiene, and food poisoning. Results showed that mothers in Saudi Arabia had moderate knowledge of food storage (passing rate $64.9 \%$ ) and usage and maintenance of kitchen facilities (passing rate $66.5 \%$ ). While they had good knowledge of personal hygiene (passing rate $83.8 \%$ ) and food poisoning (passing rate $78.5 \%$ ), their knowledge with regard to food handling was poor (passing rate $30.4 \%$ ). Results also highlighted that food safety knowledge and practices amongst mothers in Saudi Arabia improved with the level of education, while their age, employment status, monthly income, and number of children had no significant association with their food safety knowledge and practices. This research revealed the importance of education and that advance education and training program can further improve mothers' food safety knowledge and practices and thereby result in reducing the risks of foodborne illnesses at homes.
\end{abstract}

Keywords: food safety; food knowledge; food practices; food hygiene; foodborne illnesses; mothers

\section{Introduction}

Food borne illnesses are a widespread public health concern and a burden on a nation's economy [1,2]. World Health Organization (WHO) recognized foodborne illnesses and occurrences as a foremost public health threat globally of the 21st Century [3]. While everyone is vulnerable to foodborne illness, certain sections are regarded as more susceptible and thus more likely to suffer foodborne illnesses, hospitalizations, and death. These highest risk individuals, popularly known as the YOPI group include young, old, pregnant, and immunosuppressed [4,5]. Children due to their immature immune system and lower body weight are at a higher risk than adults for foodborne illnesses and these are described as one of the main factor for morbidity and mortality in developing countries [6]. About 2.2 million deaths each year in the developing world occur because of foodborne illnesses, an estimated 1.9 million of which are children. These are primarily caused by contamination of food and drinking water caused from poor sanitation or preparation [7].

Studies highlight that unsafe domestic food safety practices are increasingly linked with foodborne illnesses [8-10]. Moreover, as domestic kitchens are often used as a multipurpose area the risk of food contamination and spread of foodborne illnesses increases [11-13]. Domestic food handlers often cause contamination if they lack hygienic food handling practices [14]. Da Cunha et al. [15] also suggest that contamination can occur if foods are stored at the wrong temperature or inadequately 
packaged. While public awareness and concern about food related risks and diseases is increasing, the escalation in the number of foodborne illnesses indicates that domestic food handlers still lack adequate food safety knowledge leading to wrong food handling practices [16,17]. Scott [18] suggests that a considerable number of food borne illnesses are generally associated with practices in the domestic kitchens. Research highlights that about 50 and $87 \%$ of reported foodborne disease incidents arises within the home [19-22], enhanced by a lack of education and awareness about food safety and food handling practices [23].

Recognizing that knowledge is essential to safe food handling, many studies have focused on improving the food safety education of consumers [24-26]. Haapala and Probart [27] reported that in developed countries national initiatives are launched to find techniques to effectively educate food consumers. In developing countries, however, Ministry of Health in Saudi Arabia pointed out that there have been increasing number of foodborne illnesses in the country [28], 255 incidences occurred in 2011 alone resulting in 2066 people falling ill, majority of whom were children [29]. Nonetheless, [16] highlight that only limited research has focused on obtaining information on food safety knowledge and practices associated with improper food handling at home in Saudi Arabia. Consequently, inadequate efforts have been undertaken to reduce the risks by development of effective health education programs. As mothers are primarily the food handlers at home; to safeguard children's health and wellbeing assessing mother's beliefs and behavior and gathering information on how food becomes unsafe in the home is essential in order to reduce food hazards [30]. Also, as food preparation, handling, and storage at home cannot be regulated, for maintaining food safety at the vulnerable end of the food chain it is vital to educate domestic food handlers about the potential risks of foodborne diseases and guide safe food handling practices at home. This study therefore aims to assess food safety knowledge and practices among mothers in Saudi Arabia, so that effective health education programs can be developed with the help of sufficient information on the knowledge and practices of the target groups.

\section{Materials and Methods}

\subsection{Questionnaire Design}

To survey mothers in Saudi Arabia for their food safety knowledge and food handling practices a closed-ended questionnaire with multiple-choice questions was designed. The questionnaire development was guided by validated questionnaire used in similar studies [31-34]. Appropriate modifications were made to the questionnaire to fit the popular habits and traditions of domestic food handlers in Saudi Arabia.

The questionnaire consisted of 32 multiple-choice questions, categorized into six sections. Demographic information of each participant, such as age, educational level, employment status, income level, and number of children was asked in the first section. The questionnaire then seeks information about the participant's knowledge of food safety and practices in home kitchens through five sections, namely: knowledge of food storage (information collected through five questions), knowledge of food handling (via four questions), knowledge of the usage and maintenance of kitchen facilities (through 6 questions), knowledge of personal hygiene (through six questions) and knowledge of food poisoning (via six questions). For validation of the questionnaire a pilot study was conducted amongst food safety and business management professionals. The questionnaire was later distributed both manually and electronically to mothers in Saudi Arabia.

\subsection{Data Collection}

Surveys are an efficient tool to collect information from large volume of respondents in a short span of time [35]. The participants for this survey were selected from across Saudi Arabia for maximum coverage. However, the sampling frame covered the various demographic aspects of the questionnaire like age, place of residents, and educational level so as to safeguard a non-bias sampling. 
The questionnaires were distributed both manually and electronically and response collected between September and December 2017. A total of 1000 Saudi mothers were contacted to participate in the study, however, 21 surveys were removed as they had more than one option selected or the participants did not complete the questionnaire as they did not want to respond to the questionnaire erroneously. Thus, 979 surveys were included in this research.

\subsection{Data Analysis}

Statistical Package for the Social Sciences (SPSS) (IBM Corporation, Armonk, NY, USA) version 24 statistical package was used to analyze the data. For each question the participants were awarded one point when they answered correctly and a zero for incorrect answers and their percentages calculated for each section namely knowledge food storage, knowledge of food handling, knowledge on usage and maintenance of kitchen facilities, knowledge on personal hygiene and knowledge of food poisoning. Mean score and standard deviation for each section was analyzed, and pass rates calculated with participants who answered more than half of the questions in the section correctly attaining a pass. If the participants achieved a passing rate of $60.0 \%$ or above, they were considered to have a high level of knowledge, while a pass rate of less than $30.0 \%$ was regarded as a poor level of knowledge, and pass rates between 30-60\% were considered as moderate level of knowledge. Furthermore, the relationship between the demographic characteristics and knowledge of food safety in homes was also analyzed.

Non-parametric analysis is the most appropriate method for analyzing the data when data follows a skewed distribution [36]. Therefore, for analyzing this data, non-parametric tests (Chi-square $(\times 2)$ and Kruskal-Wallis) were used. Chi-square $(\times 2)$ test was used to compare the different demographics for their food safety knowledge and practices while Kruskal-Wallis test was used in the case of demographics of three or more independent samples, i.e., age, education level, employment status and number of children in our survey.

\section{Results and Discussion}

\subsection{Samples Profile}

Table 1 presents the demographic characteristics of the sample. $40.7 \%$ of the respondents were between the age of 36 and 50, with majority (51.5\%) being housewives. The highest educational level of the respondents $(76 \%)$ was University Degree and most respondents $(44 \%)$ had four or more children.

Table 1. The demographic characteristics of mothers in Saudi Arabia.

\begin{tabular}{|c|c|c|c|c|}
\hline Demographic Characteristics & $\mathbf{N}$ & Category & Respondents (n.) & Percentage (\%) \\
\hline \multirow[t]{4}{*}{ Age } & 979 & $18-25$ & 55 & 5.6 \\
\hline & & $26-35$ & 358 & 36.6 \\
\hline & & $36-50$ & 398 & 40.7 \\
\hline & & 51 and above & 168 & 17.2 \\
\hline \multirow[t]{4}{*}{ Children } & 979 & 1 child & 186 & 19 \\
\hline & & 2 children & 178 & 18.2 \\
\hline & & 3 children & 184 & 18.8 \\
\hline & & 4 children or more & 431 & 44 \\
\hline \multirow[t]{3}{*}{ Educational level } & 979 & Primary Education & 22 & 2.2 \\
\hline & & Secondary Education & 213 & 21.8 \\
\hline & & University Degree & 744 & 76 \\
\hline \multirow[t]{4}{*}{ Employment status } & 979 & Housewife & 504 & 51.5 \\
\hline & & Employee & 321 & 32.8 \\
\hline & & Retired & 95 & 9.7 \\
\hline & & Other & 59 & 6 \\
\hline \multirow{4}{*}{ Monthly income } & 979 & 2000-4999 SR * & 117 & 12 \\
\hline & & 5000-6999 SR & 110 & 11.2 \\
\hline & & 7000-9999 SR & 206 & 21 \\
\hline & & 10,000 SR or more & 546 & 55.8 \\
\hline
\end{tabular}




\subsection{Food Safety Knowledge and Practices of Saudi Mothers}

\subsubsection{Knowledge on Food Storage}

Table 2 presents a summary of the knowledge of domestic food handlers about food storage. Results show that majority of the respondents (73.6\%) were aware that frozen foods must be purchased at the end of the shopping. Other similar studies highlight that in Lebanon 59.7\% [32], in Greece $55.3 \%$ [37], in Jordan 73.6\% [34], participants are aware of the correct time of purchasing frozen foods when shopping. However, only 30.2\% respondents knew the correct temperature for storing frozen food. Farahat et al. [16] also highlight the poor knowledge of food safety in women in Saudi Arabia during their food purchasing and storage. A total of $70 \%$ of the respondents were knowledgeable about not freezing thawed meat for later use and storing chunks of raw meat by slicing them into smaller pieces, sealing and storing them in the freezer (77.2\%), and 37.8\% respondents knew that for consuming freshly prepared food $3 \mathrm{~h}$ later, it must be put in the fridge, and reheated when ready to eat, however, almost equal number of respondents (33.1\%) incorrectly thought that it can be covered and put on the cabinet.

Table 2. Respondents' knowledge on food storage, pass rate, mean score and standard devastation.

\begin{tabular}{|c|c|c|c|c|}
\hline Questions & $\mathbf{N}$ & Category & Respondents (n.) & Percentage $(\%)$ \\
\hline \multirow[t]{4}{*}{$\begin{array}{l}\text { 1. When is the best time to purchase } \\
\text { frozen food when shopping? }\end{array}$} & 979 & At the beginning of the shopping time & 39 & 4 \\
\hline & & At the end of the shopping time & 721 & 73.6 \\
\hline & & Whenever, does not matter & 184 & 18.8 \\
\hline & & Don't Know & 35 & 3.6 \\
\hline \multirow[t]{4}{*}{$\begin{array}{l}\text { 2. What is the optimal temperature } \\
\text { for storing frozen food? }\end{array}$} & 979 & 4 degrees Celsius & 93 & 9.5 \\
\hline & & 0 degrees Celsius & 209 & 21.3 \\
\hline & & -18 degrees Celsius or below & 296 & 30.2 \\
\hline & & Don't Know & 381 & 38.9 \\
\hline \multirow[t]{4}{*}{$\begin{array}{l}\text { 3. What should be done with freshly } \\
\text { prepared food that will be consumed } \\
3 \text { h later? }\end{array}$} & 979 & $\begin{array}{l}\text { Put in the fridge, then reheat when } \\
\text { ready to eat }\end{array}$ & 370 & 37.8 \\
\hline & & $\begin{array}{l}\text { Put in the cupboard and reheat when } \\
\text { ready to eat }\end{array}$ & 271 & 27.7 \\
\hline & & Put in the microwave oven & 14 & 1.4 \\
\hline & & Cover it and put it on the cabinet & 324 & 33.1 \\
\hline \multirow[t]{4}{*}{$\begin{array}{l}\text { 4. How should chunks of raw meat } \\
\text { be stored? }\end{array}$} & 979 & Store it directly in the freezer & 90 & 9.2 \\
\hline & & $\begin{array}{l}\text { Slice it into smaller pieces, then store } \\
\text { them in the freezer }\end{array}$ & 119 & 12.2 \\
\hline & & $\begin{array}{l}\text { Slice into smaller pieces, seal and } \\
\text { store them in the freezer }\end{array}$ & 756 & 77.2 \\
\hline & & Store it in a cool place & 14 & 1.4 \\
\hline \multirow[t]{4}{*}{$\begin{array}{l}\text { 5. Should defrosted meat be frozen } \\
\text { for later use? }\end{array}$} & 979 & Yes & 124 & 12.7 \\
\hline & & No & 685 & 70 \\
\hline & & Maybe & 149 & 15.2 \\
\hline & & Don't Know & 21 & 2.1 \\
\hline Pass Rate & & & & $64.9 \%$ \\
\hline Mean \pm standard deviation & & & & $2.8 \pm 1.1$ \\
\hline
\end{tabular}

The overall passing rate for this section was at $64.9 \%$, indicating moderate knowledge of food storage. The results highlight that while mothers in Saudi Arabia have generalized knowledge about food storage they lack a detailed understanding which impacts their practices. Langiano et al. [38] also highlight that poor food storage practices greatly increase the risk of poor food safety practices and consequently of food borne diseases. Similar results were reported by Angelillo et al. [39] who 
explored the knowledge, attitudes and related behavior on foodborne diseases and food-handling practices among mothers of children attending public schools.

\subsubsection{Knowledge on Food Handling}

Table 3 summarizes the knowledge of food handling of Saudi mothers. $54.6 \%$ of respondents knew that fruits and vegetables should be washed in running cold water. Similar studies conducted in Canada highlight that $92.5 \%$ participants are aware that fresh produce must be washed with cold running water [40], 82\% in South Africa [41], 51.4\% in Lebanon [32], 72.8\% in Greece [37], and 28.4\% in Jordan knew the correct answer [34]. Respondents also had poor knowledge about the handling leftovers, with only $31.6 \%$ being aware of the correct way of heating leftovers and only $8.8 \%$ knowing when leftovers should be discarded. Additionally, most had poor knowledge about how raw meat should be thawed, the results were in line with findings from other similar studies like in China only $38.2 \%$ respondents knew the correct way to defrost food [31] and 58.3\% in Brazil knew the correct answer [42]. Highlighting the importance of educating domestic food handlers so as to avoid cross-contamination and eliminate bacterial growth, to ultimately avoid foodborne illnesses $[10,38]$.

Table 3. Respondents' knowledge on food handling, pass rate, mean score and standard devastation.

\begin{tabular}{|c|c|c|c|c|}
\hline Questions & $\mathbf{N}$ & Category & Respondents (n.) & Percentage $(\%)$ \\
\hline \multirow[t]{4}{*}{$\begin{array}{l}\text { 1. How should vegetables and fruits } \\
\text { be washed? }\end{array}$} & 979 & Soak in Detergent & 37 & 3.8 \\
\hline & & Wash with hot water & 41 & 4.2 \\
\hline & & Wash with running cold water & 535 & 54.6 \\
\hline & & Soak in cold water, then wash & 366 & 37.4 \\
\hline \multirow[t]{4}{*}{$\begin{array}{l}\text { 2. Of the following, which is the least } \\
\text { safe way to defrost raw meat? }\end{array}$} & 979 & In the fridge & 91 & 9.3 \\
\hline & & On Chopping Board & 176 & 18 \\
\hline & & In Microwave oven & 459 & 46.9 \\
\hline & & In cold water in sealed package & 253 & 25.8 \\
\hline \multirow[t]{4}{*}{$\begin{array}{l}\text { 3. Of the following, which is the } \\
\text { correct way to heat leftovers? }\end{array}$} & 979 & Heat it to the temperature you prefer & 569 & 58.1 \\
\hline & & $\begin{array}{l}\text { Reheat is not necessary if it's during } \\
\text { the summer }\end{array}$ & 36 & 3.7 \\
\hline & & Heat until they are boiling & 309 & 31.6 \\
\hline & & Do not know & 65 & 6.6 \\
\hline \multirow{4}{*}{$\begin{array}{l}\text { 4. What should be done if the } \\
\text { leftovers are still not } \\
\text { eaten completely? }\end{array}$} & 979 & Discard them immediately & 86 & 8.8 \\
\hline & & $\begin{array}{l}\text { Put in the refrigerator immediately } \\
\text { and reheat before consuming }\end{array}$ & 741 & 75.7 \\
\hline & & $\begin{array}{l}\text { Store in kitchen and reheat before } \\
\text { consuming }\end{array}$ & 40 & 4.1 \\
\hline & & As long as they smell good, eat them & 112 & 11.4 \\
\hline Pass Rate & & & & $30.4 \%$ \\
\hline Mean \pm standard deviation & & & & $1.1 \pm 0.8$ \\
\hline
\end{tabular}

The overall passing rate for this section was at 30.4\%, highlighting poor knowledge of mothers in Saudi Arabia with regard to food handling. Farahat et al. [16] also highlight the poor knowledge of food handling in women in Saudi Arabia, while El-Sheikha [43] indicate that unsafe food handling increasingly results in bacterial food poisoning cases in Saudi Arabia. Trepka et al. [2] in their study of pregnant women and mothers in Miami, Florida also reported that the respondents had problematic food handling practices. Similar results have been reported by Parvathy et al. [44] when exploring food borne illnesses arising from home kitchens in Tamil Nadu, India. Angelillo et al. [39] also reported that mothers in Italy had poor knowledge about thawing food and handling leftovers. 


\subsubsection{Knowledge on Usage and Maintenance of Kitchen Facilities}

Results of the knowledge of Saudi mothers on the usage and maintenance of kitchen facilities are presented in Table 4 . Most respondents $(76.3 \%)$ were aware that dishes must be cleaned immediately after meals and that the same chopping board used to cut meat should not be used to cut fruits $(78.5 \%$ respondents). However, fewer number of respondents (42.3\%) knew that the correct way to clean kitchen countertop is with detergent and warm water. Similarly, respondents had poor knowledge about the recommended temperature for fridges, and where in the fridge to place raw meat, with only $34.5 \%$ and $23 \%$ respectively knowing the correct answer. While in Portugal $69.5 \%$ of respondents knew the correct fridge temperature [45], and in Wales $84.0 \%$ of the elderly had awareness about the proper temperature of the refrigerator [46].

Table 4. Respondents knowledge on usage and maintenance of kitchen facilities, pass rate, mean score, and standard devastation.

\begin{tabular}{|c|c|c|c|c|}
\hline Questions & $\mathbf{N}$ & Category & Respondents (n.) & Percentage $(\%)$ \\
\hline \multirow[t]{4}{*}{$\begin{array}{l}\text { 1. A fridge has three shelves; on } \\
\text { which shelf do you think raw meat } \\
\text { should be placed? }\end{array}$} & 979 & Top shelf & 546 & 55.8 \\
\hline & & Middle shelf & 83 & 8.5 \\
\hline & & Bottom shelf & 225 & 23 \\
\hline & & Does not matter & 125 & 12.8 \\
\hline \multirow[t]{4}{*}{$\begin{array}{l}\text { 2. What is the recommended } \\
\text { temperature for fridges? }\end{array}$} & 979 & $12^{\circ} \mathrm{C}$ & 197 & 20.1 \\
\hline & & $4{ }^{\circ} \mathrm{C}$ & 338 & 34.5 \\
\hline & & $0{ }^{\circ} \mathrm{C}$ & 42 & 4.3 \\
\hline & & Do not know & 402 & 41.1 \\
\hline \multirow[t]{4}{*}{$\begin{array}{l}\text { 3. How long should leftovers be kept } \\
\text { in the fridge? }\end{array}$} & 979 & No more than 2 days & 494 & 50.5 \\
\hline & & No more than 5 days & 220 & 22.5 \\
\hline & & As long as the food has not gone bad & 217 & 22.2 \\
\hline & & Do not know & 48 & 4.9 \\
\hline \multirow[t]{4}{*}{$\begin{array}{l}\text { 4. Of the following, which is the } \\
\text { correct way to clean the kitchen } \\
\text { countertop and stove? }\end{array}$} & 979 & Clean with dry rag & 7 & 0.7 \\
\hline & & Clean with wet rag & 36 & 3.7 \\
\hline & & $\begin{array}{l}\text { Clean with detergent and warm } \\
\text { water }\end{array}$ & 414 & 42.3 \\
\hline & & All of the above & 522 & 53.3 \\
\hline \multirow[t]{4}{*}{$\begin{array}{l}\text { 5. Of the following, which do you } \\
\text { think is the correct way to } \\
\text { wash dishes? }\end{array}$} & 979 & $\begin{array}{l}\text { Soak in water, after several hours, } \\
\text { wash with the same water }\end{array}$ & 16 & 1.6 \\
\hline & & Wash immediately after meal & 747 & 76.3 \\
\hline & & $\begin{array}{l}\text { Wash in water basin, dry with dish } \\
\text { cloth }\end{array}$ & 162 & 16.5 \\
\hline & & Other & 54 & 5.5 \\
\hline \multirow{4}{*}{$\begin{array}{l}\text { 6. Cutting meat on a chopping board } \\
\text { and using the same chopping board } \\
\text { for cutting fruit. Of the following, } \\
\text { which are the correct ways? }\end{array}$} & 979 & $\begin{array}{l}\text { Rinse the chopping board with hot } \\
\text { water before cutting fruit }\end{array}$ & 20 & 2 \\
\hline & & $\begin{array}{l}\text { Use the other side of the chopping } \\
\text { board to cut fruit }\end{array}$ & 79 & 8.1 \\
\hline & & $\begin{array}{l}\text { Clean the chopping board with } \\
\text { detergent and hot water before } \\
\text { cutting fruit }\end{array}$ & 111 & 11.3 \\
\hline & & $\begin{array}{l}\text { Use another chopping board to cut } \\
\text { fruit }\end{array}$ & 769 & 78.5 \\
\hline Pass Rate & & & & $66.5 \%$ \\
\hline Mean \pm standard deviation & & & & $3.1 \pm 1.2$ \\
\hline
\end{tabular}


The overall passing rate for this section was at $66.5 \%$, indicating moderate knowledge of usage and maintenance of kitchen facilities amongst mothers in Saudi Arabia. To avoid pathogenic growth or cross-contamination to maintain food safety it is critically important to have knowledge in usage and maintenance of kitchen facilities [38,46]. Similar results were observed by Usfar et al. [47] in their study of urban mothers in Indonesia. However, unlike the current study, Angelillo et al. [39] have reported a higher number of respondents being aware of correct way to clean kitchen countertop when exploring the knowledge of mothers of children attending public schools in Italy.

\subsubsection{Knowledge on Personal Hygiene}

Table 5 presents a summary of the knowledge of personal hygiene in Saudi mothers. Results show $65.3 \%$ respondents knew the correct way of washing hands was with running warm water using soap and then wiping them dry. Similarly, $60.5 \%$ knew that as long as gloves are worn it is safe to handle food with wound on the back of the hand. Mothers in Saudi Arabia had better knowledge in this regard as compared to results observed similar studies in China, with only $25.5 \%$ participants being aware of the correct answer [31], 29.1\% in Brazil [42], 19.6\% in Greece [37], and 23.0\% in Jordan [34]. Almost all the respondents $(95.8 \%)$ knew the correct way to wash hands after handling raw meat while only a fewer number $(49.2 \%)$ were aware that people with diarrhea, fever, sore throat or flu symptoms should not cook for others. Similarly, 97.0\% in South Africa [41], 75.6\% in Ghana [48], $57.5 \%$ in Greece [37], and $96.1 \%$ of university students in Saudi Arabia indicated that they wash their hands before handling or preparing foods [49]. Results also indicate that an almost similar number of respondents ( $49.2 \%$ and $44.4 \%$, respectively) regarded diarrhea, fever, sore throat, flu, and AIDS patients as not suitable to cook for others lest they can cause food contamination. This highlights the need and importance of capturing information on the knowledge and practices of the target groups and utilizing it for the development of effective health education programs. The overall passing rate for this section was at $83.8 \%$, highlighting that mothers in Saudi Arabia had good knowledge with regard to personal hygiene. Fawzi and Shama [19] also reported that women working in Alexandria University, Egypt were very knowledgeable with regard to personal hygiene. Others studies have also suggested that food handlers have a significantly good knowledge of personal hygiene [50,51]. 
Table 5. Respondents knowledge on personal hygiene, pass rate, mean score, and standard devastation.

\begin{tabular}{|c|c|c|c|c|}
\hline Questions & $\mathbf{N}$ & Category & Respondents (n.) & Percentage $(\%)$ \\
\hline \multirow[t]{3}{*}{$\begin{array}{l}\text { 1. Is it safe to handle food if you have a wound on } \\
\text { the back of your hand? }\end{array}$} & 979 & Yes, as long as the wound is not infected & 33 & 3.4 \\
\hline & & Yes, as long as the wound has a bandage on it & 274 & 28 \\
\hline & & Not at all & 80 & 8.2 \\
\hline \multirow[t]{3}{*}{$\begin{array}{l}\text { 2. Of the following, which is the correct way to } \\
\text { wash hands? }\end{array}$} & 979 & Wash with running cold water, wipe dry & 70 & 7.2 \\
\hline & & $\begin{array}{l}\text { Wash hands with cold water in a basin, use soap and then } \\
\text { wash hands with cold water in the basin, wipe dry }\end{array}$ & 201 & 20.5 \\
\hline & & $\begin{array}{l}\text { Wash hands with running warm water, use soap and } \\
\text { then wash with running warm water, wipe dry }\end{array}$ & 639 & 65.3 \\
\hline \multirow[t]{3}{*}{$\begin{array}{l}\text { 3. Of the following, which is the correct way to } \\
\text { wash hands after handling raw meat? }\end{array}$} & 979 & Wipe with towel & 2 & 0.2 \\
\hline & & Wash with cold water, wipe dry & 14 & 1.4 \\
\hline & & Wash with warm water, wipe dry & 25 & 2.6 \\
\hline \multirow[t]{4}{*}{$\begin{array}{l}\text { 4. After touching which of the following should } \\
\text { you wash your hands during the course of } \\
\text { preparing food? }\end{array}$} & 979 & Face & 10 & 1 \\
\hline & & A pimple on the surface of skin & 116 & 11.8 \\
\hline & & Clothes & 7 & 0.7 \\
\hline & & All of the above & 846 & 86.4 \\
\hline \multirow[t]{4}{*}{$\begin{array}{l}\text { 5. People with which of the following symptoms } \\
\text { should not cook for others? }\end{array}$} & 979 & Diarrhea, Fever, Sore throat or Flu & 482 & 49.2 \\
\hline & & Skin allergies & 56 & 5.7 \\
\hline & & AIDS & 435 & 44.4 \\
\hline & & Headache & 6 & 0.6 \\
\hline Pass Rate & & & & $83.8 \%$ \\
\hline Mean \pm standard deviation & & & & $3.6 \pm 1.2$ \\
\hline
\end{tabular}




\subsubsection{Knowledge on Food Poisoning}

Table 6 presents the knowledge of Saudi mothers on food poisoning. A total of $61.2 \%$ respondents knew that the most important method for preventing food poisoning was to keep it refrigerated until it's time to serve it. Respondents had poor knowledge about which foods can cause food poisoning, with only $10.5 \%$ reporting that it can be caused by raw or undercooked beef and eggs. Other studies highlight that in China undercooked beef was regarded as a cause of food poisoning by $25.3 \%$ respondents, raw eggs by $8.9 \%$, and both by $12.2 \%$ [31], in Portugal respondents were divided for the same as $12.5 \%, 19.0 \%$ and $43.8 \%$, respectively [45], in South Africa $64.3 \%$ regarded raw eggs as a cause of food poisoning [41], 44.1\% in Ghana [48], and 52.9\% in Jordan considered undercooked eggs as unsafe [34]. While $45.4 \%$ respondents knew that Salmonella sp. poisoning can be prevented by fully heating food, most respondents $\left(49.9 \%\right.$ ) did not know if bacteria could be killed by freezing at $-18{ }^{\circ} \mathrm{C}$ but $53.2 \%$ were aware that raw beef or chicken are most likely to be contaminated with Escherichia Coli (E. coli).

The overall passing rate for this section was at 78.5\%, indicating good knowledge of food poisoning amongst Saudi mothers. Lum et al. [50] also report that food handlers are knowledgeable with regard to food poisoning; Ahmed [14], however, reported that in Yemen mothers' knowledge about food poisoning was not satisfactory. 
Table 6. Respondents knowledge on food poisoning, pass rate, mean score, and standard devastation.

\begin{tabular}{|c|c|c|c|c|}
\hline Questions & $\mathbf{N}$ & Category & Respondents (n.) & Percentage $(\%)$ \\
\hline \multirow[t]{4}{*}{$\begin{array}{l}\text { 1. Which of these foodstuffs is more likely to provoke } \\
\text { food poisoning if eaten? }\end{array}$} & 979 & Fruits taken out of the refrigerator immediately & 41 & 4.2 \\
\hline & & Unheated canned food & 29 & 3.0 \\
\hline & & Raw or undercooked beef and eggs & 806 & 82.3 \\
\hline & & Other & 103 & 10.5 \\
\hline \multirow[t]{4}{*}{$\begin{array}{l}\text { 2. Which is the most important method for preventing } \\
\text { food poisoning? }\end{array}$} & 979 & Spray the kitchen with insecticides weekly & 29 & 3 \\
\hline & & Avoid eating leftovers & 110 & 11.2 \\
\hline & & Keep food refrigerated until it's time to serve them & 599 & 61.2 \\
\hline & & $\begin{array}{l}\text { Use detergent to disinfect kitchen countertop and stove } \\
\text { weekly }\end{array}$ & 241 & 24.6 \\
\hline \multirow[t]{4}{*}{ 3. Can bacteria in food be killed by freezing at $-18^{\circ} \mathrm{C}$ ? } & 979 & Yes, totally & 71 & 7.3 \\
\hline & & Yes, partly & 235 & 24 \\
\hline & & Not at all & 184 & 18.8 \\
\hline & & Do not know & 489 & 49.9 \\
\hline \multirow[t]{4}{*}{ 4. How to prevent Salmonella poisoning? } & 979 & Fully heat food & 444 & 45.4 \\
\hline & & Wash food with very hot water & 79 & 8.1 \\
\hline & & Freeze food for more than 3 days & 57 & 5.8 \\
\hline & & Do not know & 399 & 40.8 \\
\hline \multirow[t]{4}{*}{$\begin{array}{l}\text { 5. Which of the following is most likely to become } \\
\text { contaminated with Escherichia Coli (E. coli)? }\end{array}$} & 979 & Tap water & 28 & 2.9 \\
\hline & & Raw beef or chicken & 521 & 53.2 \\
\hline & & Raw vegetables & 83 & 8.5 \\
\hline & & Do not know & 347 & 35.4 \\
\hline \multirow[t]{4}{*}{ 6. Who is more at risk of getting a foodborne illness? } & 979 & Children & 119 & 12.2 \\
\hline & & Pregnant women & 30 & 3.1 \\
\hline & & Elderly & 17 & 1.7 \\
\hline & & All of the above & 813 & 83 \\
\hline Pass Rate & & & & $78.5 \%$ \\
\hline Mean \pm standard deviation & & & & $3.5 \pm 1.2$ \\
\hline
\end{tabular}


3.3. Association between the Demographic Characteristics of Participants and Their Food Safety Knowledge and Practices

Table 7 presents the relationship between the demographic characteristics of Saudi mothers and their food safety knowledge and practices. Their mean score and overall passing rate using the non-parametric tests (Chi-square $(\times 2)$ and Kruskal-Wallis) are also reported. The study highlights that while mothers in Saudi Arabia had good food safety knowledge, their food handling practices were poor, and there is scope for improvements in their food safety knowledge and practices (Figure 1). Results show that education is a significant factor that impacts the food safety knowledge and practices among Saudi mothers. On the other hand, age $(\mathrm{N}=979 ; p$ value 0.330$)$, number of children $(\mathrm{N}=979$; $p$ value 0.181$)$, employment status $(\mathrm{N}=979 ; p$ value 0.891$)$, and monthly income $(\mathrm{N}=979 ; p$ value 0.356), do not have any significance with regard to impacting their food safety knowledge and practices.

Table 7. The relationship between the demographic characteristics of participants and their food safety knowledge and practices.

\begin{tabular}{|c|c|c|c|c|c|}
\hline Variables & $\mathbf{N}$ & $\begin{array}{c}\text { Pass Rate } \\
(\%)\end{array}$ & $p$-Value & $\begin{array}{l}\text { Mean } \\
\text { Score }\end{array}$ & $p$-Value \\
\hline Age & 979 & & 0.330 & & 0.132 \\
\hline $18-25$ & & $5 \%$ & & 13.2 & \\
\hline $26-35$ & & $35.40 \%$ & & 14.1 & \\
\hline $36-50$ & & $41.60 \%$ & & 14.2 & \\
\hline 51 and above & & $17.90 \%$ & & 14.1 & \\
\hline How many children do you have? & 979 & & 0.181 & & 0.233 \\
\hline 1 child & & $17.30 \%$ & & 13.7 & \\
\hline 2 children & & $17.60 \%$ & & 14.1 & \\
\hline 3 children & & $19.30 \%$ & & 14.3 & \\
\hline 4 children or more & & $45.70 \%$ & & 14.2 & \\
\hline Educational level & 979 & & 0.045 & & 0.157 \\
\hline Primary Education & & $2.10 \%$ & & 13.0 & \\
\hline Secondary Education & & $21.60 \%$ & & 13.8 & \\
\hline University Degree & & $76.30 \%$ & & 14.2 & \\
\hline Employment status & 979 & & 0.891 & & 0.185 \\
\hline Housewife & & $53.80 \%$ & & 14.3 & \\
\hline Employed & & $30.20 \%$ & & 13.9 & \\
\hline Retired & & $9.40 \%$ & & 13.9 & \\
\hline Other & & $6.60 \%$ & & 14.3 & \\
\hline What is your monthly income? & 979 & & 0.356 & & 0.158 \\
\hline 2000-4999 SR * & & $11 \%$ & & 13.5 & \\
\hline 5000-6999 SR & & $10.60 \%$ & & 14.0 & \\
\hline 7000-9999 SR & & $21.10 \%$ & & 14.1 & \\
\hline $10,000 \mathrm{SR}$ or more & & $57.30 \%$ & & 14.3 & \\
\hline
\end{tabular}

* SR: Saudi Riyal. 


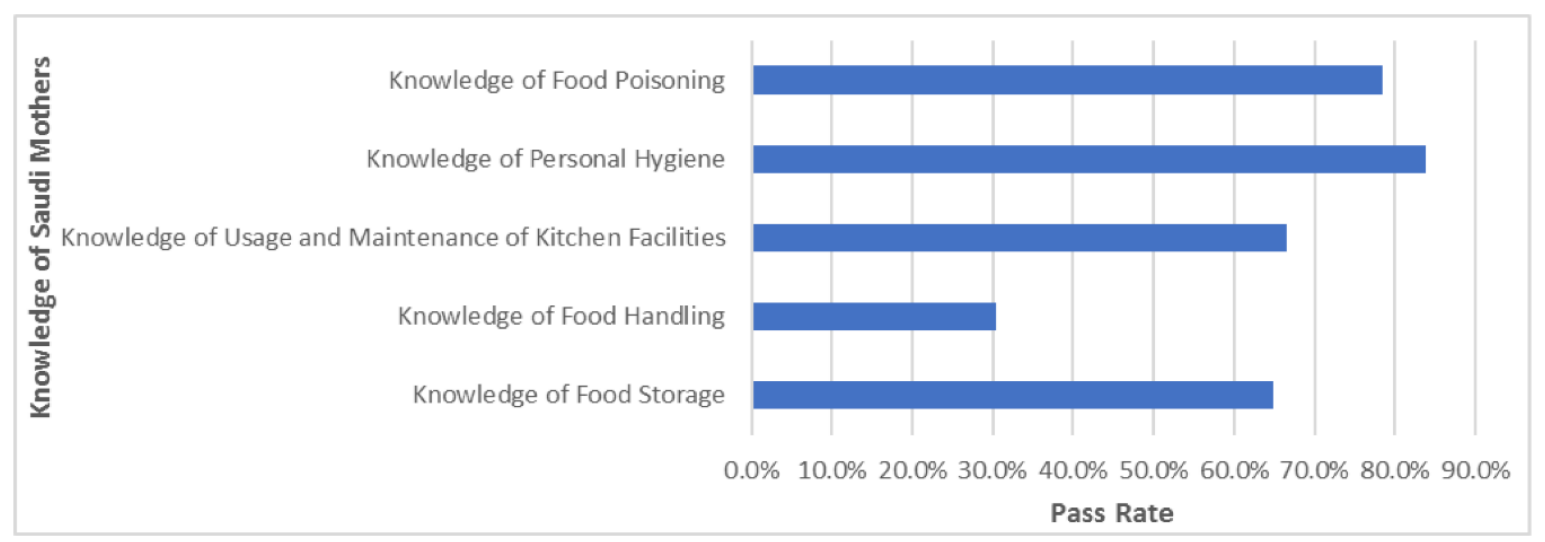

Figure 1. Pass rate for knowledge of food safety among Saudi mothers (Knowledge levels-Low: Pass rate up to $30 \%$; Moderate: Pass rate 30-60\%; High: Pass rate above $60 \%$ ).

Mothers between the age of 36-50 year were better with food safety knowledge and practices with a pass rate of $41.6 \%$. Housewives were more knowledgeable with a pass rate of $53.8 \%$ and those who had four or more children reported a better pass rate of $45.7 \%$. Additionally, results showed that higher monthly income Saudi mothers were better with their food safety knowledge and practices and had a pass rate of $57.3 \%$.

The results correlate with other studies that highlight the importance of education and that of educational programs for mothers in improving their food safety knowledge and practices [39,47]. Furthermore, the findings highlight that the necessity of gathering information of domestic food handlers' beliefs and behavior in order to reduce the risks of foodborne diseases and guide safe food handling practices at home. WHO [1] also suggest the advance education is comprehensively required so as to assist lessening foodborne illnesses and for comprehending the issue of why food safety is a globally epidemic.

\section{Conclusions}

This study assessed the food safety knowledge and practices among mothers in Saudi Arabia. The information could be used as a starting point to design education and training programs that can further improve their knowledge and can be translated into better and safer food handling practices. Food safety efforts generally tend to focus on food supply chains and the household domain of food handling and practices gets limited attention. Food handlers in households need effective and methodical education and training to safeguard themselves and their families from getting food-borne illnesses. It is, therefore, recommended that authorities, researchers, educators, media, and food safety communicators should initiate education programs, with special focus on the high-risk groups like mothers and food handlers at home to advance the food safety knowledge and safer food practices.

Author Contributions: W.O.A. undertook the investigation, methodology and wrote the original draft of the article. A.P. and A.K.J. conceptualized the research, conducted formal analysis, supervised, and conducted review and editing of the article.

Funding: This research received no external funding.

Acknowledgments: The authors would like to acknowledge the support and facilities provided by Dublin Institute of Technology, Dublin, Ireland. The researcher Wafa Ayaz would also like to thank the Saudi Ministry of Higher Education and the Saudi Government for the scholarship that enabled her to continue her studies.

Conflicts of Interest: The authors declare no conflict of interest. 


\section{References}

1. World Health Organization (WHO). Complex Food Chain Increases Food Safety Risks. 2015. Available online: http:/ / www.euro.who.int/en/media-centre/sections/press-releases/2015/03/complexfood-chain-increases-food-safetyrisks (accessed on 12 January 2018).

2. Trepka, M.J.; Newman, F.L.; Dixon, Z.; Huffman, F.G. Food safety practices among pregnant women and mothers in the women, infants, and children program, Miami, Florida. J. Food Prot. 2007, 70, 1230-1237. [CrossRef] [PubMed]

3. World Health Organization (WHO). WHO Estimates of the Global Burden of Foodborne Diseases: Foodborne Disease Burden Epidemiology Reference Group 2007-2015; WHO: Geneva, Switzerland, 2015.

4. Beharielal, T.; Thamaga-Chitja, J.; Schmidt, S. Pre-and post-harvest practices of smallholder farmers in rural KwaZulu-Natal, South Africa: Microbiological quality and potential market access implications. Food Control 2018, 92, 53-62. [CrossRef]

5. Barkley, J.; Viveiros, B. Preventing foodborne and enteric illnesses among at-risk populations in the United States and Rhode Island. R.I. Med. J. 2016, 99, 25.

6. Buzby, J.C. Children and microbial foodborne illness. Food Rev. 2001, 24, 32-37.

7. Sudershan, R.; Rao, G.S.; Rao, P.; Rao, M.V.V.; Polasa, K. Food safety related perceptions and practices of mothers-A case study in Hyderabad, India. Food Control 2008, 19, 506-513. [CrossRef]

8. Hassan, H.F.; Dimassi, H.; Karam, Z.N. Self-reported food safety knowledge and practices of Lebanese food handlers in Lebanese households. Br. Food J. 2018, 120, 518-530. [CrossRef]

9. Young, I.; Waddell, L. Barriers and facilitators to safe food handling among consumers: A systematic review and thematic synthesis of qualitative research studies. PLoS ONE 2016, 11, e0167695. [CrossRef] [PubMed]

10. Mountjoy, B. A Consumer's Guide to Food Safety Risks. 2014. Available online: http:/ /www.foodinsight. org/A_Consumer_s_Guide_to_Food_Safety_Risks (accessed on 17 July 2018).

11. Mkhungo, M.C.; Oyedeji, A.B.; Ijabadeniyi, O.A. Food safety knowledge and microbiological hygiene of households in selected areas of Kwa-Zulu Natal, South Africa. Ital. J. Food Saf. 2018, 7, 6887. [CrossRef] [PubMed]

12. National Health Services (NHS). Beware of Common Household Germs. 2014. Available online: http: //www.nhs.uk/Livewell/homehygiene/Pages/common-household-germs.aspx (accessed on 11 July 2018).

13. Byrd-Bredbenner, C.; Berning, J.; Martin-Biggers, J.; Quick, V. Food safety in home kitchens: A synthesis of the literature. Int. J. Environ. Res. Public Health 2013, 10, 4060-4085. [CrossRef] [PubMed]

14. Ahmed, W.A.M. Mothers' Knowledge Regarding Preventive Measures of Food Poisoning in Yemen. Food Nutr. Sci. 2015, 6, 49. [CrossRef]

15. Da Cunha, D.T.; Stedefeldt, E.; De Rosso, V.V. Perceived risk of foodborne disease by school food handlers and principals: The influence of frequent training. J. Food Saf. 2012, 32, 219-225. [CrossRef]

16. Farahat, M.F.; El-Shafie, M.M.; Waly, M.I. Food safety knowledge and practices among Saudi women. Food Control 2015, 47, 427-435. [CrossRef]

17. McCarthy, M.; Brennan, M.; Kelly, A.; Ritson, C.; De Boer, M.; Thompson, N. Who is at risk and what do they know? Segmenting a population on their food safety knowledge. Food Qual. Preference 2007, 18, $205-217$. [CrossRef]

18. Scott, E. Foodborne disease and other hygiene issues in the home. J. Appl. Bacteriol. 1996, 80, 5-9. [CrossRef] [PubMed]

19. Fawzi, M.; Shama, M.E. Food safety knowledge and practices among women working in Alexandria University, Egypt. Egypt Public Health Assoc 2009, 84, 95-117.

20. Jevšnik, M.; Hlebec, V.; Raspor, P. Consumers' awareness of food safety from shopping to eating. Food Control 2008, 19, 737-745. [CrossRef]

21. Redmond, E.C.; Griffith, C.J. Consumer food handling in the home: A review of food safety studies. J. Food Prot. 2003, 66, 130-161. [CrossRef] [PubMed]

22. Raspor, P.; Jevšnik, M.; Hlebec, V. Consumers' Awareness of Food Safety from Shopping to Eating; Consortium International Congress on Food Safety: Brussels, Belgium, 2006; p. 112.

23. Jevšnik, M.; Hoyer, S.; Raspor, P. Food safety knowledge and practices among pregnant and non-pregnant women in Slovenia. Food Control 2008, 19, 526-534. [CrossRef] 
24. Garayoa, R.; Cordoba, M.; Garcia-Jalon, I.; Sanchez-Villegas, A.; Vitas, A.I. Relationship between consumer food safety knowledge and reported behavior among students from health sciences in one region of Spain. J. Food Prot. 2005, 68, 2631-2636. [CrossRef] [PubMed]

25. Kennedy, J.; Jackson, V.; Cowan, C.; Blair, I.; McDowell, D.; Bolton, D. Consumer food safety knowledge: Segmentation of Irish home food preparers based on food safety knowledge and practice. Br. Food J. 2005, 107, 441-452. [CrossRef]

26. Lin, C.-T.J.; Jensen, K.L.; Yen, S.T. Awareness of foodborne pathogens among US consumers. Food Qual. Preference 2005, 16, 401-412. [CrossRef]

27. Haapala, I.; Probart, C. Food safety knowledge, perceptions, and behaviors among middle school students. J. Nutr. Educ. Behav. 2004, 36, 71-76. [CrossRef]

28. Al-Shabib, N.A.; Mosilhey, S.H.; Husain, F.M. Cross-sectional study on food safety knowledge, attitude and practices of male food handlers employed in restaurants of King Saud University, Saudi Arabia. Food Control 2016, 59, 212-217. [CrossRef]

29. Ministry of Health. Ministry of Health Portal. Saudi Arabia. 2013. Available online: http://www.moh.gov. sa/en/Ministry/Pages/default.aspx (accessed on 17 July 2018).

30. Worsfold, D.; Griffith, C.J. Assessment of the standard of consumer food safety behavior. J. Food Prot. 1997, 60, 399-406. [CrossRef]

31. Gong, S.; Wang, X.; Yang, Y.; Bai, L. Knowledge of food safety and handling in households: A survey of food handlers in Mainland China. Food Control 2016, 64, 45-53. [CrossRef]

32. Hassan, H.F.; Dimassi, H. Food safety and handling knowledge and practices of Lebanese university students. Food Control 2014, 40, 127-133. [CrossRef]

33. Moreb, N.A.; Priyadarshini, A.; Jaiswal, A.K. Knowledge of food safety and food handling practices amongst food handlers in the Republic of Ireland. Food Control 2017, 80, 341-349. [CrossRef]

34. Osaili, T.M.; Obeidat, B.A.; Jamous, D.O.A.; Bawadi, H.A. Food safety knowledge and practices among college female students in north of Jordan. Food Control 2011, 22, 269-276. [CrossRef]

35. McLeod, S. Questionnaires. Simply Psychology. 2014. Available online: www.simplypsychology.org/ questionnaires.html (accessed on 12 January 2018).

36. Sullivan, L. Nonparametric Test. Boston University School of Public Health, 2016. Available online: http: / / sphweb.bumc.bu.edu/otlt/MPH-Modules/BS/BS704_Nonparametric/BS704_Nonparametric2.html (accessed on 12 January 2018).

37. Lazou, T.; Georgiadis, M.; Pentieva, K.; McKevitt, A.; Iossifidou, E. Food safety knowledge and food-handling practices of Greek university students: A questionnaire-based survey. Food Control 2012, 28, 400-411. [CrossRef]

38. Langiano, E.; Ferrara, M.; Lanni, L.; Viscardi, V.; Abbatecola, A.M.; De Vito, E. Food safety at home: Knowledge and practices of consumers. J. Public Health 2012, 20, 47-57. [CrossRef] [PubMed]

39. Angelillo, I.F.; Foresta, M.R.; Scozzafava, C.; Pavia, M. Consumers and foodborne diseases: Knowledge, attitudes and reported behavior in one region of Italy. Int. J. Food Microbiol. 2001, 64, 161-166. [CrossRef]

40. Burke, T.; Young, I.; Papadopoulos, A. Assessing food safety knowledge and preferred information sources among 19-29 year olds. Food Control 2016, 69, 83-89. [CrossRef]

41. Sibanyoni, J.J.; Tshabalala, P.A.; Tabit, F.T. Food safety knowledge and awareness of food handlers in school feeding programmes in Mpumalanga, South Africa. Food Control 2017, 73, 1397-1406. [CrossRef]

42. Uggioni, P.L.; Salay, E. Consumer knowledge concerning safe handling practices to prevent microbiological contamination in commercial restaurants and socio-demographic characteristics, Campinas/SP/Brazil. Food Control 2012, 26, 331-336. [CrossRef]

43. El Sheikha, A.F. Food safety issues in Saudi Arabia. Nutr. Food Technol. 2015, 1, 1-4.

44. Padma Parvathy, G. Awareness and Attitudes of Food Safety Knowledge and Practices of Mothers. Res. J. Econ. Bus. Stud. 2012, 1, 19-24.

45. Carbas, B.; Cardoso, L.; Coelho, A.C. Investigation on the knowledge associated with foodborne diseases in consumers of north eastern Portugal. Food Control 2013, 30, 54-57. [CrossRef]

46. Evans, E.W.; Redmond, E.C. Older adult consumer knowledge, attitudes, and self-reported storage practices of ready-to-eat food products and risks associated with Listeriosis. J. Food Prot. 2016, 79, 263-272. [CrossRef] [PubMed] 
47. Usfar, A.A.; Iswarawanti, D.N.; Davelyna, D.; Dillon, D. Food and personal hygiene perceptions and practices among caregivers whose children have diarrhea: A qualitative study of urban mothers in Tangerang, Indonesia. J. Nutr. Educ. Behav. 2010, 42, 33-40. [CrossRef] [PubMed]

48. Akonor, P.T.; Akonor, M.A. Food Safety Knowledge: The case of domestic food handlers in Accra. Eur. J. Food Res. Rev. 2013, 3, 99. [CrossRef]

49. Sharif, L.; Al-Malki, T. Knowledge, attitude and practice of Taif University students on food poisoning. Food Control 2010, 21, 55-60. [CrossRef]

50. Lum, L.; Albrecht, J.A.; Yaseen, M.; Litchfield, R.; Ritter-Gooder, P. Food handling practices and knowledge among families with young children. Food Prot. Trends 2013, 33, 358-375.

51. Patil, S.R.; Cates, S.; Morales, R. Consumer food safety knowledge, practices, and demographic differences: Findings from a meta-analysis. J. Food Prot. 2005, 68, 1884-1894. [CrossRef] [PubMed]

(C) 2018 by the authors. Licensee MDPI, Basel, Switzerland. This article is an open access article distributed under the terms and conditions of the Creative Commons Attribution (CC BY) license (http://creativecommons.org/licenses/by/4.0/). 